\title{
THE VULNERABILITY OF THE CHURCH - ECCLESIOLOGICAL OBSERVATIONS
}

\author{
Leo J Koffeman ${ }^{1}$ \\ Protestantse Theologische Universiteit, Utrecht, The Netherlands \\ Systematic Theology and Ecclesiology \\ Stellenbosch University
}

\begin{abstract}
The Decade to Overcome Violence requires a spirituality that acknowledges one's own vulnerability. What does this mean for ecclesiology? The author suggests distinguishing four aspects, i.e. physical, moral, communicative and compassionate vulnerability. In order to prevent an abstract, if not docetic type of ecclesiology, the key issue is how to deal with the moral vulnerability of the church. Several traditional strategies are no longer really satisfactory. A preferable way to keep ecclesiology connected with real church life is by taking liturgy as the point of departure. Furthermore, the author suggests to distinguish four 'quality markers' of the church, to be used to link the theological proprietates of the church of faith with the practical aspects of church life: inclusivity, authenticity, conciliarity and integrity. Different aspects of vulnerability can be connected with these quality markers.
\end{abstract}

Keywords: Ecclesiology, Church Law, Liturgy, Vulnerability, Sin

The World Council of Churches' 8th Assembly (Harare, Zimbabwe, 1998) launched the Decade to Overcome Violence (DOV). The conclusion of DOV will be marked by an International Ecumenical Peace Convocation, to be held in May 2011, in Kingston, Jamaica. One of the goals of DOV is 'to challenge the churches to overcome the spirit, logic and practice of violence, to relinquish any theological justification of violence, and to affirm anew the spirituality of reconciliation and active non-violence'. ${ }^{2}$

At the Porto Alegre 2006 Assembly of the World Council of Churches a Mid-term Report of DOV was presented. An interesting statement in this report reads: "The praxis of non-violence must be rooted in a spirituality that acknowledges one's own vulnerability and is able, at the same time, to resist being caught in the mentality of perpetrator and victim". 3 Ecumenical documents like this one usually include a lot of such 'musts' and 'shoulds'. Probably it is inevitable to do so. But what would it really mean for churches to 'acknowledge their own vulnerability'? My question is, if we can read these words of the

\footnotetext{
Leo J Koffeman is Professor of Church Law and Ecumenism, Protestant Theological University (Utrecht), and Professor Extraordinary of Systematic Theology and Ecclesiology, Stellenbosch University.

2 Cf. Mid-term of the Ecumenical Decade to Overcome Violence 2001-2010: Churches Seeking Reconciliation and Peace, Geneva 2006, § II; http://www.oikoumene.org/en/resources/documents/assembly/porto-alegre2006/3-preparatory-and-background-documents/mid-term-of-the-ecumenical-decade-to-overcome-violence2001-2010.html (July 23, 2009).

Mid-term, $\S \mathrm{IV} / 2$.
} 
Mid-term Report as an ecclesiological statement. What does it mean to take vulnerability seriously in ecclesiology? Is something like a 'vulnerable ecclesiology' possible?

Vulnerability necessarily refers to life as we experience it. It does not make sense to speak of vulnerability on a very abstract level. The most recent international ecumenical dialogue between de Roman Catholic Church and the World Methodist Council the following sentences says:

The Church is a community of weak and vulnerable human beings who often fail and fall, alone and together. (...) There is a danger of presenting an idealised picture which bears little resemblance to the visible reality of the Church as it has journeyed and struggled through history. ${ }^{4}$

These words speak to my concern. How - if at all - is the visible reality of the church being reflected in our theological discourse on the church, i.e. in ecclesiology? Of course, to some extent it is. For instance, issues like ordained ministry or the sacraments, which are key issues in ecclesiology, cannot be dealt with without any reference to the visible reality of the church? But is that all?

It is the sometimes baffling triviality and ambiguity of church life that first of all challenges me as a theologian, and more specifically as a 'church lawyer'. For me this refers to certain aspects of the vulnerability of the church.

It may not be difficult to recognize courageous and ground-breaking decisions of churches - even if no such decision goes without opposition. Where synods take a strong confessing stand, we may easily identify with them. In a South African context I think I don't even need to specify this. On the other hand in some instances we whole-heartedly reject certain ecclesial actions, if it is beyond doubt that they jeopardize the integrity of the proclamation of the Gospel, and no less that of the church involved. Again, we may all have the same examples in mind. But what makes me wonder as a theologian is the large grey area in between, between strong confessional stands on the one hand and evident heresy on the other. Or, in moral rather than confessional terms: between spiritual heroism and abject cowardice or injustice.

Vulnerability, like we see it in the triviality and ambiguity of church life, has many faces. One face is inertia, ${ }^{5}$ for instance when a church in no way meets the challenges as inherent to its social-political context. Or when a church in its pastoral, catechetical and liturgical practice simply ignores the progress made in ecumenical dialogue. Another face is bureaucracy, for instance when church representatives on a denominational level tend to find ever new legal requirements which make it impossible to accommodate what a local congregation really deems necessary.

\section{Nico Koopman}

In an article in the Journal of Reformed Theology Nico Koopman gave some thorough insights into the vulnerability of the church, but from a different perspective. His view of vulnerability is not inspired by the perplexities of church life, but by a strong conviction with regard to the mission of the church. He takes his point of departure in the church as

4 GGYC (The grace given you in Christ. Catholics and Methodists reflect further on the Church, 2006), §50. See: http://www.vatican.va/roman_curia/pontifical_councils/chrstuni/meth-councildocs/rc_pc_chrstuni_doc_20060604_seoul-report_en.html (July 23, 2009).

5 Cf. Leo J Koffeman, 'An asymptotic dialogue. A response to Jeffrey Gros', in: E van der Borght (ed.), The Unity of the Church: A Theological State of the Art and Beyond, Brill Leiden 2009 (forthcoming). 
church of the triune God: "Faith in the triune God is faith in the vulnerable God". ${ }^{6}$ In the suffering of Jesus God shows his compassion for us. Like many ecumenical theologians today, Koopman refers to the three Cappadocians and their emphasis on the interdependence of the three Persons in the Trinity. The relationships between the three Persons have to be described in terms of origin rather than in terms of identity. In this context the ecumenical orthodox theologian Zizioulas speaks of the 'ecstatic' character of God. Koopman summarizes:

Ecstasis means that God's being is determined by his radical search for communion with the other. In fact, God is communion. In Jesus Christ, who became human, we are part of this communion. In this communion God finds his true being. This choice for ecstasis, for communion with his creatures, expresses the vulnerability of God (...) The vulnerability of God is manifested in the relations of interdependence between Father, Son and Spirit. It reaches its culmination point in the cross of Jesus Christ, and it comes to expression in the compassion, sympathy, concern, and solidarity of the triune God with a suffering world. From this vulnerable God (...) the church receives her essence, identity, and mission.?

Koopman reflects ecumenical ecclesiological insights that we can also find in the Faith and Order study document The Nature and Mission of the Church ${ }^{8}$ (NMC). This so-called koinonia ecclesiology has been central in both multilateral and bilateral ecumenical dialogue for several decades now. It's basic conviction is: the Church is not merely the sum of individual believers living in communion with God and among themselves. "It is their common partaking in the life of God (2 Pet 1:4), who as Trinity is the source and focus of all communion". 9 In NMC, too, this view implies compassion, sympathy, concern, and solidarity with a suffering world: "Because koinonia is a participation in Christ crucified and risen, it is also part of the mission of the Church to share in the sufferings and hopes of humankind". ${ }^{10}$ This view of the mission of the church is broader developed in the second part of NMC chapter I, on 'the Church of the Triune God'. ${ }^{11}$ It for instance says:

As Christ's mission encompassed the preaching of the Word of God and the commitment to care for those suffering and in need, so the apostolic Church in its mission from the beginning combined preaching of the Word, the call to repentance, faith, baptism and diakonia. This the Church understands as an essential dimension of its identity. ${ }^{12}$

In speaking of the vulnerability of the triune God and of the church, Koopman highlights and in a way radicalizes these aspects of ecclesiology. Vulnerability is 'part of the essence of the church'. "This vulnerability is based in the vulnerability of the triune God (...), as well as in the vulnerability of human beings". 13 "The vocation, mission, ethics, and public theology of such a church is determined by the notion of vulnerability". ${ }^{14}$ According to Koopman this kind of vulnerability determines the relevance of the church:

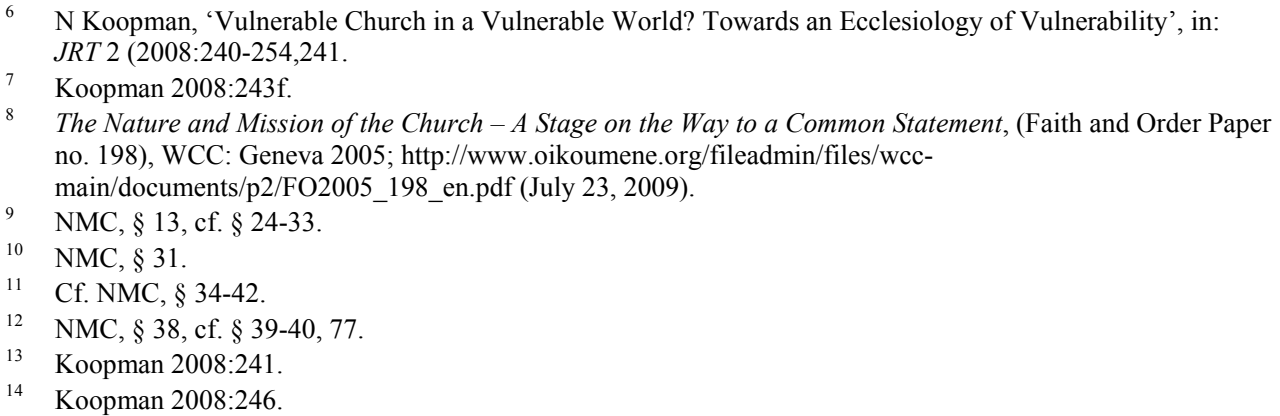


To be church is to stand where God stands - i.e., in a special way, by way of priority, and primarily with the most vulnerable. This principle constitutes the parameters for the ethics of the vulnerable church. The moral status of our customs, traditions, policies, and practices in all walks of life is determined by the question: how do they impact the most vulnerable ones in specific, concrete situations? ${ }^{15}$

The reference to the Belhar Confession ${ }^{16}$ is obvious. The strength of Koopman's approach is that 'vulnerability' has one clear meaning. Vulnerability is a quality of the triune God and of the church, which comes to expression in compassion, sympathy, concern, and solidarity with a suffering world. The cross of Jesus Christ is its culmination point. Therefore, the church is called to stand with the vulnerable, the poor, the destitute, and the wronged - with the victims of violence in all of its manifestations.

It seems to be clear that Koopman's interpretation of the vulnerability of the church is quite different from the interpretation I started this contribution with: vulnerability like we see it in the triviality and ambiguity of church life. One of the questions we have to deal with is: how are these different interpretations related? Do we use the same term for two completely different phenomena, or is it possible to bring them together into one picture?

\section{Aspects of Vulnerability}

The church is a vulnerable community and a vulnerable institution in many respects, basically both in its relation to its context and in its internal dynamics. 'Vulnerability' is a multi-layered term. My proposal is to distinguish four aspects, i.e. physical, moral, communicative and compassionate vulnerability.

1. First of all, physical vulnerability. It refers to a physical risk of being subjected to violence, being damaged, hurt, destroyed, or killed; hardly anything is more vulnerable than a newborn baby. From that perspective the vulnerability of churches is inversely proportional to its size and/or power. The Protestant Church in the Netherlands can hardly be seen as vulnerable, but the Lutheran part of its constituency, containing no more than one percent of its membership, is. ${ }^{17}$

2. Secondly, moral vulnerability. The term vulnerability can also be used in a moral context, and refer to the risk for someone to loose integrity and to give in to certain temptations. People can be vulnerable in terms of alcohol or drugs abuse, but also in terms of violence, inclined to the abuse of power. If we say, with the Roman Catholic - Methodist dialogue: "the Church is a community of weak and vulnerable human beings who often fail and fall, alone and together", 18 this is meant. Violence plays a role in church life.

Both these interpretations - physical and moral vulnerability - seem to point to negative connotations of vulnerability. But we can also speak of positive forms of vulnerability:

3. Thirdly, I distinguish communicative vulnerability. We sometimes speak of vulnerability as a virtue. 'Presenting oneself in a vulnerable way' is supposed to be a

\footnotetext{
Ibid 2008:250

6 Cf. Belhar Confession, § 4; http://www.ngkerk.org.za/VGKSA/documents/BelharConfession.doc (July 23, 2009).

17 Koopman refers to this aspect only indirectly: "To be church in a vulnerable world is to be a vulnerable church. This is the case even though the membership numbers of the church might be high" (241).

18 See supra, footnote 4.
} 
positive quality. It then means: to be not too defensive, but open for fair criticism and debate, and ready to learn from new experiences, even if they at first sight might seem threatening. Such vulnerability, indeed, makes it possible to 'resist being caught in the mentality of perpetrator and victim'. ${ }^{19}$

4. Finally, compassionate vulnerability. This is how I want to characterize Koopman's understanding of vulnerability.

So, I distinguish four different aspects or interpretations of vulnerability. How can they be related in ecclesiology?

\section{Essence and Reality}

Ecclesiology has developed into one of the main fields of work in ecumenical theological research, particularly within the Faith and Order Commission. The most recent results of multilateral dialogue in this area were published in NMC. Already in the structure of this study document we can recognize the struggle to do justice to the tension between what we believe the church to be and what we can experience in day-to-day church life.

The decisive line of thinking is 'top-down', i.e. from the essence of the church to its visible reality. First, chapter I of NMC deals with 'the Church of the Triune God', and therefore with its 'nature and mission', and then chapter II speaks about 'the Church in History' from the perspective of its being a 'Church in via'. This approach is very common, and it indeed has its advantages. Most of all, it makes it easy to recognize biblical and other traditional 'high' insights, images and metaphors. Characteristics of the church as 'the people of God', 'the Body of Christ', and 'the temple of the Holy Spirit' can be given a 'safe' place in the first part of theological discourse. The same goes for the Nicene proprietates: the Church is one, holy, catholic and apostolic. But it is exactly this 'safe place' that might be problematic after all.

The (necessary) distinction between the essence of the church and its visible reality can easily result in a full division of both. All questionable aspects of church life then find their natural place in the second part of ecclesiological discourse, about the church in via. This is where the negative aspects of the vulnerability of the church - and especially its moral vulnerability - can be taken into account, in fact by way of concession: the church in its essence is one or catholic, the Body of Christ or a 'sign and instrument of God's intention and plan for the world, ${ }^{20}$ but we have to admit: in practice it often is not; or at least its reality is ambiguous. Fortunately, we can identify positive signs of what the church 'in essence is' in what we see in church history and in present-day church life. Nevertheless, a lot of it does not meet the standards of the essential nature of the church.

In NMC we see this approach clearly in the way the Nicene proprietates are being dealt with in the second chapter. As an example, let me quote the paragraph on apostolicity:

The essential apostolicity of the Church stands in contrast to shortcomings and errors of the churches in their proclamation of the Word of God. Nevertheless, this apostolicity is witnessed to in the many ways in which the Church, under the guidance of the Holy Spirit, has been faithful to the testimony of the apostles concerning Jesus Christ. The Church is called to return continuously to the apostolic truth and to be renewed in its worship and mission stemming from its apostolic origin (cf. Acts 2:42-47). By doing so

Mid-term, § IV/2; see supra, footnote 3.

20 Cf. NMC, § 43-47. 
it makes visible, and does justice to, the apostolic Gospel which is already given to it and works in it in the Spirit, making it the Church. ${ }^{21}$

On the one hand, there is the essential apostolicity of the Church, to a certain degree visible in its faithfulness to the testimony of the apostles. On the other hand we see shortcomings and errors of the churches in their proclamation of the Word of God. But they seem not to be very relevant. Both aspects are bridged in the call to return to the apostolic truth and to be renewed in worship and mission.

In many ecclesiological studies and official church documents we see a similar approach. In such cases in fact three aspects of ecclesiology are being taken into account. Ecclesiology is about what the church 'in essence is', and/or it is about what the church 'should be', and/or - in an eschatological perspective - it is about what the church 'will be'.

The focus on 'what the church in essence is' is common in ecclesiology, as we saw from the structure of NMC. The focus on 'what the church should be' usually is being presented as an ethical consequence of this essence of the church. It is in fact also the core of Koopman's article: compassionate vulnerability is part of the essence of the church, and therefore the church is called to be vulnerable. The same could go for what I called 'communicative vulnerability': it can be based on a koinonia ecclesiology, and therefore materialize as an aspect of the calling of the church.

In a similar way, ecumenical documents use to say: because the church is one, it should be one, etc. In other words: the unity of the church - and the same goes for all other essential characteristics of the church - is at the same time a gift and a calling. ${ }^{22}$ And as far as the church we see is not what it is called to be, we live from hope: one day the church will be what it should be. Gift and calling imply a promise.

However, all three of these aspects tend to distract attention from the triviality and ambiguity of 'what the church is - and is not - in reality'. The focus on gift, calling and promise easily leads to a type of ecclesiology in which what people experience in day-today church life is taken less seriously as theologically not decisive, or even ignored as totally irrelevant. This is where I want to try and take some further steps.

\section{Moral Vulnerability}

In my view the role of physical, communicative and compassionate vulnerability in the church can only be fully valued if we know how to deal with its moral vulnerability. If not, our ecclesiology might easily become too abstract, if not docetic. Undoubtedly, the most difficult aspect of the vulnerability of the church - in terms of how we experience day-today church life and, by consequence, in terms of ecclesiological thinking - is this moral one. Physical vulnerability - especially as it is manifest after decades of secularization in my Dutch context - may sometimes discourage us, we nevertheless have several theological strategies to cope with it. The physical vulnerability of the church might even be romanticized and be seen as a sign - or proof? - of its integrity: 'a true church should not be part of the power structures of this world'.

Communicative and compassionate vulnerability have a strong ethical connotation and can at least easily be integrated into our view of what the church should be like. But it is

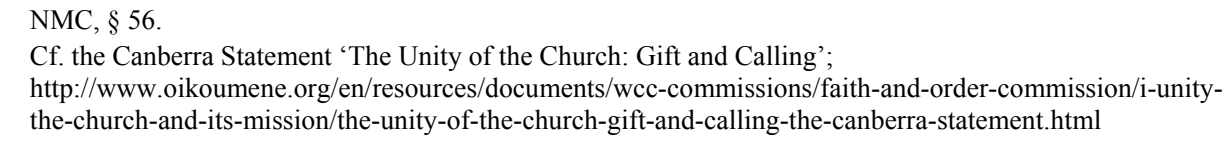


exactly this 'should be' that raises fundamental questions. To what extent do we recognize communicative vulnerability in the churches we are part of? Are they really open for fair criticism and debate, and ready to learn from new experiences? And what about compassionate vulnerability? Do they really stand with the vulnerable, the poor, the destitute, and the wronged? How does violence play a role in this all? A church can be an accessory to, if not directly guilty of violence. It is the church's moral vulnerability that really challenges our ecclesiological concepts.

In the history of ecclesiology this challenge, of course, has been recognized. How can we adequately take into account the sins of the church (if this wording is appropriate at all)? Quite a few strategies which have traditionally been used, are not really satisfactory any more - if they ever were. Let me mention five of them, partly overlapping one another.

1. A strong division between the invisible and the visible aspects of the church makes it possible to keep the invisible 'true essence' of the church apart from the visible and sinful 'appearances' of the church; in fact, ecclesiological docetism serves as an answer - or an escape - here.

2. By way of paradoxical ecclesiology, others find a solution in an analogical use of the Lutheran simul iustus ac peccator, speaking of the church as simul iusta ac peccatrix (cf Luther: casta meretrix, a chaste whore), and sometimes so in an unhistorical way: then a sterile status quo is the result.

3. Besides that, Reformed ecclesiology tended to use the distinction between 'the true church' and 'the false church(es)' to cope with this theological problem. It is clear that this is an extremely idealistic approach: it can only been maintained for some time in the aftermath of church reform (mostly resulting in secession) and at the expense of ecumenical awareness. Moral vulnerability cannot be prevented by opting out. The adage ecclesia reformata semper reformanda in itself already contradicts this strategy.

4. E.g. Roman Catholic doctrine works with another distinction, between the church and its members. The sins of the members of the church, including those of its most representative members like the bishops and the pope, do not really affect the holiness of the church itself: "the Church, embracing in its bosom sinners, at the same time holy and always in need of being purified (sancta simul et semper purificanda), always follows the way of penance and renewal". ${ }^{23}$

5. Yet another 'solution' is given in a radically eschatological ecclesiology. In the eschaton the Church will be the spotless bride of Christ (cf Eph 5:25-27), but for now we should not have any expectation of the churches as we experience them. Sin is part of the 'already', purity is part of the 'not yet'.

In NMC disputed ecclesiological issues which cannot (yet) be formulated in terms of convergence between the different traditions are being dealt with in so-called 'boxes', paragraphs which by means of a specific lay-out can be directly recognized as needing further debate. The issue of 'the church and sin' is the subject of such a box, immediately after paragraph 56, i.e. following the second exposé on the Nicene proprietates, from the perspective of "the sometimes continual tension in the historical life of the Church between that which is already given and that which is not yet fully realized". ${ }^{24}$

23 Second Vatican Council, Lumen Gentium, § 8; http://www.vatican.va/archive/hist_councils/ii_vatican_council/ documents/vat-ii_const_19641121_lumen-gentium_en.html

$24 \mathrm{NMC}, \S 52$. 
In this box we first find a statement all churches can share: "All the churches agree that there is sin, corporate and individual, in the Church's history (cf Rev 2:2)". But the churches differ as to how this reality should be understood and expressed. Without connecting them with specific confessional traditions, three different approaches are identified. For some, it is impossible to say: 'the Church sins'. The church is first of all a gift of God, and therefore it cannot sin. This gift is lived out in fragile human beings who are liable to $\sin$, but the sins of the members of the Church are not the sins of the Church. This is the fourth strategy mentioned above.

The second and third approaches are described in these words:

Others, while they too state that the Church, as the creature of God's Word and Spirit, the body of Christ, is holy and without sin, say at the same time that it does sin. They say this because they define the Church as the communion of its members who - although they are justified believers brought to birth by the Spirit, and Christ's own body - in this world are still sinful human beings (cf 1 Jn 1:8-10).

Yet others believe that while one cannot speak of the sins of the Church, sin in the Church may become systemic and also affect the institution.

The difference between the second approach and the first one lies in the fact that in defining the church the second one takes the communion of its members as its point of departure, whereas the first one starts from the opposite perspective, the church as a gift of God. This second approach seems to be dominant in protestant ecclesiology, which usually is based on a view of the church as the sum total of believers (congregatio fidelium). A strength of the third approach might be its awareness of the institutional aspects of the church. Rather than going into a deeper analysis of these approaches ${ }^{25}$ I want to refer to the way this 'box' tries to make a step towards an ecumenical solution of the issue of 'the church and sin'. I quote the final sentences:

While there are these different understandings concerning the Church and sin, we ask whether all churches might not be able to agree on the following proposition: The relationship between sin and holiness in the Church is not a relationship of two equal realities, because sin and holiness do not exist on the same level. Rather, holiness denotes the Church's nature and God's will for it, while sinfulness is contrary to both (cf 1 Cor 15:21-26).

I assume that the suggested proposition as such is acceptable. But to what extent does it really solve the problem? Certainly, sinfulness is contrary to the Church's nature and is contrary to God's will for the church, but this does not answer the question as to how ecclesiology can recognize the trivial and ambiguous facts in church life.

One of the classical theological sentences I heard as a student forty years ago and I have never forgotten is: 'nondum considerasti quanti ponderis sit peccatum'. ${ }^{26}$ 'You have not yet taken into account the full weight of sin' - it is how Anselm of Canterbury reacts to interpretations of reconciliation in Christ which in his view miss the point. In a similar way ecclesiology might miss the point as long as the moral vulnerability of the church has not been taken into account. Of course, the church is built on the forgiveness of sins. But how decisive this may be, sin of the church can neither be ignored, nor accommodated or

25 I intensively dealt with the same issues in: Leo J. Koffeman, 'The Nature of Sin in the Church', in: ME Brinkman en HPJ Witte (ed.), From Roots to Fruits (European Studies of the World Alliance of Reformed Churches, Nr. 3), Geneva: WARC, 1998:79-99. Cf. Leo J Koffeman, Het goed recht van de kerk. Een theologische inleiding op het kerkrecht, Kampen 2009:264-271.

26 Anselmus Cantuariensis, Cur Deus Homo?, I 21. 
explained. It is still there, and it is part and parcel of the church in its earthly manifestation, as a community and an institution under the continuous threat of loosing its integrity. NMC's statement that sin and holiness do not exist on the same level, does not really help in this respect. In a way, it still sounds too 'balanced'. But may be the discussion as such is far too abstract on the NMC level. The ecumenical deadlock in this respect conceals and reveals interests of all churches in terms of legitimizing historical decisions. So, let us try to come closer to real church life again.

\section{Liturgical Ecclesiology}

In my view the best way to keep ecclesiology connected with real church life is by taking liturgy as the point of departure of ecclesiological thinking. ${ }^{27}$ What the church is, is first of all recognizable in a normal Sunday morning worship service, where the Word of God is being proclaimed and the sacraments are being administered. Here we can see that the church is first of all creatura Verbi, living out of the living Word of God. Here the church 'happens'. This is also where 'ecclesiology from above' - like: the church is the una sancta catholica apostolica - and 'ecclesiology from below' - like: the church is the sum total of believers - meet. The church as koinonia lives from the grace of God, who in the power of the Holy Spirit shares his life with us in the proclamation of the Word and the administration of baptism and holy supper. Nowhere the church is more visible than here. The liturgy is the locus ecclesiologicus par excellence.

Based on this, we can make a number of ecclesiological distinctions. One of them is the distinction between ordained ministry and the community. Both are essential aspects of the church, as liturgy already shows. Their interplay is vital. From one perspective we could say that the community should have priority. It all boils down to the way men and women live their daily life as Christians. The 'mission of the Church to share in the sufferings and hopes of humankind', ${ }^{28}$ is fulfilled in the way ordinary church members show compassion, sympathy, concern, and solidarity. To a large extent we have no possibility to perceive this: it is the mainly hidden reality of the 'salting salt'. It is also difficult to determine the moral vulnerability of the church in this respect. If a church community turns a blind eye to violence in society or to the role its own culture plays in maintaining structures of injustice, this is ecclesiologically relevant. It is not enough and not even possible to reduce such cultural biases to the individual responsibility or guilt of individual church members. Of course, each of them plays his/her own role, but the whole is more then the sum total of the parts. The culture of a community itself needs to be addressed in ecclesiology.

From another perspective we could as well say that ordained ministry should have priority: at least on the long run the sincere proclamation of the Word of God by devoted ministers is constitutive of the church. This brings us closer to the institutional aspects (including the legal aspects) of the church, and at least there the moral vulnerability of the church has to be taken seriously. That is where the triviality and the ambiguity of the church certainly cannot be neglected.

So, in my view liturgy, community and ministry together have to be taken as the point of departure of ecclesiological thinking, rather than an abstract definition of the 'essence' of the church or a sociological description of the characteristics of present-day church-life. This insight is also decisive in terms of church law. Church law is 'liturgical' in nature: it

7 Cf Koffeman 2009:101-113.

28 Cf NMC, § 31 . 
has to find its decisive contents and structures from a reflection on what liturgy is. For this very reason ecclesiology and church law necessarily have to be contextual, or at least contextualized. If not, it hardly makes sense to speak about the qualities (proprietates) and characteristics (notae) of the church. This also applies to the vulnerability of the church: is can only be assessed in a specific context, which determines its position in society (physical vulnerability), its risks of failure and corruption (moral vulnerability), its possibilities and needs to be open for fair criticism and debate, and ready to learn from new experiences (communicative vulnerability), and its calling to express compassion, sympathy, concern, and solidarity God with a suffering world (compassionate vulnerability).

\section{Quality Markers}

The theological discipline of church law has to be rooted in sound ecclesiology. But how can and should church law and ecclesiology be related? I would suggest ${ }^{29}$ to distinguish four 'quality markers' of the church, to be used to link the theological proprietates of the church of faith with the practical aspects of church life. These quality markers can function as criteria in the way we analyze and shape daily church life in a specific context, and they can help us to assess what can and should be done in terms of church legislation to make the church as an institution better meet these standards. The following quality markers might play a role here.

1. Inclusivity, as derived from the catholicity of the church we believe, and first of all related to the purpose of the church. A church cannot accept 'self-evident' mechanism of exclusion, be they ethnic, social, economic, or cultural in nature. It is aware of the relative significance of its historical constituency, and of the need to go beyond them, in mission and diaconate. This requires institutional provisions.

2. Authenticity, as derived from the apostolicity of the church we believe, and first of all related to the sources of the church. Holy Scripture and tradition determine church life. A church needs certain structures and procedures to safeguard this to the best of its abilities.

3. Conciliarity as derived from the unity of the church we believe, and first of all related to the relations within the church - and between churches. In its institutional form a church should facilitate communication between people and groups within the church, to foster a community in which the gifts of all contribute to the calling of the church.

4. Integrity, as derived from the holiness of the church we believe, and first of all related to the boundaries of the church. Not everything can be accepted within a church. Sometimes churches need to say 'no'.

It is possible to connect different aspects of vulnerability with these quality markers. Compassionate vulnerability, as far as the institutional side of the church is concerned, is directly related to the inclusivity of a church. In terms of church law we need to ask ourselves, if not the way we organize our churches effectively excludes people who are victims of the violence incorporated in our social, economic, and cultural systems. The church is not only supposed to be a church for or with those who suffer but also a church of those who suffer.

Communicative vulnerability is even more dependent on the way we organize church life, including the regulations of church law. Here conciliarity is decisive, which includes -

29 Cf Koffeman 2009:163-181. 
using another ecumenical key word - mutual accountability. Do our ecclesial structures, both on a local and a supra-local level, really foster communication? Are our church law stipulations really helping the church to be open for fair criticism and debate, and to be ready to learn from new experiences? Checks and balances in the way power is distributed within the church, as well as adequate legal procedures to prevent and fight power abuse, are pivotal in this respect.

Of course, in all these cases the issue is not only church law as a set of regulations. Church life is more than church law. And much depends on the way we use our procedures. But I am convinced that church law can play an important role in creating and maintaining a church, characterized by both compassionate and communicative vulnerability.

But what about moral vulnerability? As far as I can see this is in fact the reverse side of the same medal. If churches put in place adequate church law provisions in order to foster compassionate and communicative vulnerability, they at the same time reduce the risks of moral vulnerability. All human institutions are vulnerable in this respect; churches are no exception. That is exactly why we need to enhance the church's compassionate and communicative vulnerability.

\section{Finally, Vulnerable Ecclesiology?}

So much about the vulnerability of the church. Some final thoughts should be given to vulnerable ecclesiology. That is not the same. Also our way of dealing with the church from a theological perspective is not beyond the risk of not recognizing its own vulnerability.

In my view this is where primarily communicative vulnerability is important. Ecclesiology should be vulnerable, in the sense of: not defensive, open for criticism and debate, ready to learn. This is not new, of course. It is a self-evident aspect of academic theology. But for ecclesiology nowadays it points to two very important requirements.

On the one hand communicative vulnerability implies that ecclesiology should go beyond the traditional confessional frameworks that for centuries have determined this theological locus. Ecclesiology is ecumenical in nature ${ }^{30}$ interconfessional and intercultural exchange is a necessary condition of sound ecclesiological thinking.

On the other hand, it says that ecclesiology should always be related to the church in real life and in its specific context, not giving in to the temptation to idealize the church. Therefore, ecclesiology is necessarily a form of public theology.

30 Cf the German church law expert Hans Dombois, who sees the theological discipline of church law as ecumenical in nature. 


\section{BIBLIOGRAPHY}

Leo J Koffeman 1998. 'The Nature of Sin in the Church', in: ME Brinkman en HPJ Witte (ed.), From Roots to Fruits (European Studies of the World Alliance of Reformed Churches, Nr. 3), Geneva: WARC.

Leo J Koffeman 2009. Het goed recht van de kerk. Een theologische inleiding op het kerkrecht, Kampen.

Leo J Koffeman 2009. 'An asymptotic dialogue. A response to Jeffrey Gros', in: E van der Borght (ed.), The Unity of the Church: A Theological State of the Art and Beyond, Brill: Leiden (forthcoming).

N Koopman 2008. 'Vulnerable Church in a Vulnerable World? Towards an Ecclesiology of Vulnerability', in: JRT 2.

Internet: Documents of the Uniting Reformed Church in Southern Africa.

Belhar Confession; http://www.ngkerk.org.za/VGKSA/documents/BelharConfession.doc Internet: Documents of the World Council of Churches.

The Unity of the Church: Gift and Calling (The Canberra Statement); http://www.oikoumene.org/en/resources/documents/wcc-commissions/faith-andorder-commission/i-unity-the-church-and-its-mission/the-unity-of-the-church-giftand-calling-the-canberra-statement.html

The Nature and Mission of the Church - A Stage on the Way to a Common Statement, (Faith and Order Paper no. 198), WCC: Geneva 2005; http://www.oikoumene.org/fileadmin/files/wccmain/documents/p2/FO2005_198_en.pdf

Mid-term of the Ecumenical Decade to Overcome Violence 2001-2010: Churches Seeking Reconciliation and Peace, Geneva 2006; http://www.oikoumene.org/en/resources/documents/assembly/porto-alegre-2006/3preparatory-and-background-documents/mid-term-of-the-ecumenical-decade-toovercome-violence-2001-2010.html

Internet: Documents of the Roman Catholic Church.

GGYC (The grace given you in Christ. Catholics and Methodists reflect further on the Church, 2006; http://www.vatican.va/roman_curia/pontifical_councils/chrstuni/meth-councildocs/rc_pc_chrstuni_doc_20060604_seoul-report_en.html

Second Vatican Council, Lumen Gentium, § 8; http://www.vatican.va/archive/hist_councils/ii_vatican_council/documents/vatii_const_19641121_lumen-gentium_en.html 